d milk, and he showed a dislike eggs. When he began flying he d the rule of the yard.

Ho would tease the cats, eat the icken's feed and scare them, and hen Dad milked he would sit on the ws' necks.

One day we built a tin tray where placed his food. When the ickens tcok his food, he ruffed his feathers and flew-cawing ter the chickens, although he sharhis food with the sparrows.

When strangers came he would fly them and their car and because is never succeeded in scaring them, flew away and stayed out of ght until they left.

In August, his mother came and ied to persuade him to go away cm humans, but he solemnly reused. Then one night he got locked with the chickens and got squeezd and ruffed up. I've never seen a ird show his feelings or converse plainly as he did.

Shortly after this accident he left, lthough he visited us regularly. efore he went scuth he came back nd cawed until Mom went ou' and hen he circled around the pole and ft. I'm sure he'll come back in the pring.

\section{STRIPED SQUIRREL}

y Bonnie Frew, age 15, Pense, Sask. My personal experienze with wild fe was with a striped squirrel more ommonly known as a striped goher. Although these animals are estructive they can sometimes be amed with a lot of patience.

M.y first experience with a striped opher happened at my aunt's. She ad several striped gophers on hər lace. One became so used to me hat he wculd not even run; that is, I did not frighten him by a sudden nove. One day I decided to try an xperiment. I put a marshmallow on long stick and held it out to the triped gopher. At first the stripcd opher was very cautious but then le began to nibble at the marshmalcw and then finally to eat it. I did ot have any more experiences with his particular striped gopher because had to leave for home the next day.

A few years later on our farm we iad another striped gopher that got oo tame as far as the chickens were oncerned. One day our pet red ooster took after the striped gopher and chased him to the gopher hole. It was really funny looking at the rooster with his neck stuck down the gopher hole trying to get the gopher and the way that rooster strutted across the yard when it found out it could not get the striped gopher.

So you see, you can have fun with wild life even though they are supposed to be so destructive.

\section{TWO DETERMINED TREE SWALLOWS}

By Janice Bradshaw, age 11,
Saltccats, Sask.

Last spring we noticed two tree swallows sitting on the muffler of the little tractor which stood near the barn. My dad didn't use this tractor very often because he had a larger one. One day he wanted to gc harrowing so he started the little tractor and out of the muffler flew iwigs and grass. The tree swallows had started to make their nest in the muffler.

Just as my dad finished harrowing, the traztor ran out of gas so he walked home, leaving the tractor in the field abcut three quarters of a mile away. About three days later when he went for the tractor, twigs and grass flew out of the muffler again when he started it. He then noticed the swallows around. They must have followed the tractor out to the field.

When the tractor was back in the yard, we noticed the swallows began their work of building their nest in the muffler again. They were so determined to make their home in the muffler that my dad tcok off the muffler and placed it on the combine nearby. The nest was soon completed and eggs laid in it.

For the rest of the spring season the tractor was used without the muffler.

\section{AN ADVENTURE WITH A GARTER SNAKE}

by Ed Andres, age 9, Rosthern, Sask

One time in a town close to Swift Current a friend of mine and myself found some garter snakes. We played with them for a while. I had one in my hand. My friend put the snake he had around his neck. After we played with them we put them where we found them. They were very friendly. 